\title{
OVERVIEW
}

\section{Kebijakan Moneter dan Aktivitas Ekonomi}

\author{
Perry Warjiyo ${ }^{1}$
}

Keampuhan kebijakan moneter dalam mempengaruhi aktivitas ekonomi merupakan salah satu isu yang paling lama diperdebatkan dalam ekonomi moneter. Dapatkah uang mempengaruhi output riil, atau akankah ia hanya meningkatkan inflasi? Konsensus dalam literatur empiris menunjukkan bahwa hubungan jangka panjang antara pertumbuhan uang dengan inflasi berkorelasi sempurna, sehingga mendukung pandangan paham monetarist bahwa inflasi selalu dan dimanapun merupakan fenomena moneter. ${ }^{2}$ Karena itu, kestabilan harga perlu menjadi tujuan yang diutamakan oleh bank sentral karena hal demikian merupakan kontribusi optimal dari kebijakan moneter dalam mendukung pembangunan ekonomi berkelanjutan.

Namun demikian, terdapat pula kepentingan dalam ekonomi moneter, khususnya untuk formulasi kebijakan, yang terpusat pada pertanyaan apakah kebijakan moneter dapat dipergunakan secara efektif untuk mempengaruhi aktivitas ekonomi riil dalam jangka pendek. Jika demikian halnya, apakah dapat dipertimbangkan bagi bank sentral untuk menempuh kebijakan moneter aktif dalam menstimulasi aktivitas ekonomi riil, atau haruskah bank sentral tetap konsisten pada mandat pemeliharaan kestabilan harga? Dalam kaitan ini, hubungan jangka pendek antara pertumbuhan uang, output riil, dan inflasi akan tergantung pada bagaimana respons para pelaku ekonomi swasta terhadap kejutan-kejutan yang terjadi dalam perekonomian, maupun pada bagaimana bank sentral bereaksi terhadap kejutan-kejutan dimaksud. Karena itulah, korelasi jangka pendek akan bervariasi baik antar negara, karena bank sentral menerapkan kebijakan moneter yang berbeda, maupun antar waktu, karena sumber-sumber kejutan ekonomi juga bervariasi.

1 Direktur, Pusat Pendidikan dan Studi Kebanksentralan, Bank Indonesia.

2 Bab satu dari buku Carl E. Walsh (2001), Monetary Theory and Policy, memberikan ulasan yang bagus mengenai teknik dan bukti empiris mengenai hubungan antara uang, harga, dan output. 
Isu pengaruh jangka pendek dari kebijakan moneter terhadap aktivitas ekonomi juga penting bagi negara-negara yang terkena krisis, seperti Indonesia, dengan meningkatnya tuntutan terhadap bank sentral mengenai peran terbaik dari kebijakan moneter dalam berkontribusi pada upaya penanganan berbagai permasalahan yang muncul dari krisis maupun pada upaya mendorong pemulihan ekonomi. Lebih khusus lagi, tekanan-tekanan pada melemahnya nilai tukar serta besar dan cepatnya dampak penularannya pada inflasi mengharuskan bank sentral untuk lebih waspada dalam mengendalikan likuiditas perekonomian untuk menjaga kestabilan nilai mata uang yang diperlukan untuk menumbuhkan kepercayaan pada pemulihan ekonomi. Tetapi, di sisi lain pengetatan moneter yang sekonyong-konyong dan dalam waktu lama akan menyebabkan melonjaknya suku bunga dan terbatasnya ketersediaan dana yang diperlukan sektor riil untuk bertahan hidup dalam krisis ekonomi. Pemahaman yang baik tentang hubungan jangka pendek antara uang, output, dan harga akan dapat memberikan petunjuk bagi otoritas moneter mengenai rumusan optimal kebijakan moneter dalam menimbang antara pemeliharan kestabilan harga dengan stimulus pertumbuhan ekonomi dalam periode yang sulit tersebut.

Prosedur dan instrumen kebijakan moneter merupakan isu penting lainnya bagi bank sentral dalam merumuskan kebijakan moneter. Setelah bank sentral memutuskan berapa target inflasi yang wajar dan asumsi pertumbuhan ekonomi yang menyertainya, pertanyaannya kemudian adalah bagaimana kebijakan moneter tersebut akan dijalankan untuk mencapai tujuan tersebut, dalam arti bahwa: (i) target operasional apa yang dipergunakan, yaitu uang primer atau suku bunga jangka pendek; (ii) target antara atau variabel informasi kebijakan apa yang harus dimonitor, misalnya besaran moneter, suku bunga jangka menengah, kredit, dan nilai tukar; dan (iii) bagaimana mekanisme transmisi kebijakan moneter tersebut dalam mempengaruhi output riil dan harga. Pemahaman tentang isu-isu ini akan mempunyai implikasi pada perilaku bank sentral dalam merancang kebijakan moneternya untuk merespons berbagai kejutan dalam perekonomian, dan karenanya akan berdampak besar pada sifat hubungan jangka pendek antara uang, output, dan harga.

Edisi Buletin kali ini mengangkat lagi sejumlah studi yang berkaitan dengan topik keampuhan kebijakan moneter dalam mempengaruhi aktivitas ekonomi di Indonesia. Topiktopik yang disajikan mencakup kebijakan moneter dalam era pasca krisis Indonesia, instrumen kebijakan moneter yang optimal, pengaruh upah minimum pada kesempatan kerja, dan pelajaran dari currency board system di Argentina untuk Indonesia. Dua artikel yang pertama berkaitan dengan sederetan makalah mengenai pencarian kerangka kebijakan moneter yang baru untuk Indonesia, dan mereka dimaksudkan untuk melengkapi sejumlah studi yang pernah dilakukan dalam area ini yang lebih dikenal dengan kerangka inflation 
targeting. ${ }^{3}$ Artikel ketiga melihat pada sektor riil dengan menganalisis dampak kebijakan upah minimum yang ditempuh pemerintah dalam beberapa tahun terakhir sebagai salah satu upaya untuk membantu kesejahteraan pekerja. Sementara itu, artikel yang terakhir memberikan sejumlah argumen yang meyakinkan untuk menentang usulan penerapan currency board system sebagai alternatif kerangka kebijakan moneter di Indonesia.

Artikel pertama berjudul "Monetary Policy in Post Crisis Indonesia:Some Lessons Learned" menyajikan kontribusi yang begitu menarik dari Anglingkusumo pada studi mengenai efektivitas kerangka kebijakan moneter dan komitmen yang tinggi pada stabilitas harga. Ditunjukkan bahwa kerangka pentargetan uang primer telah cukup berhasil dalam mengendalikan munculnya kembali tekanan-tekanan inflasi dalam periode krisis di Indonesia. Penulis mengkaitkan keberhasilan awal ini dengan adanya hubungan ekonomi ala monetarist yang didukung dengan efektifnya penerapan kerangka pentargetan uang primer tersebut. Pada khususnya, terdapat hubungan kuat dari pertumbuhan tahunan uang dalam arti sempit (uang primer, uang kartal, dan M1) yang mendahulu inflasi IHK, dan bahwa dalam jangka panjang inflasi menunjukkan homogenitas secara sempurna terhadap uang sempit. Lebih jauh lagi, seluruh kelebihan pasokan uang sempit (M1 disequlibria) di atas kebutuhan riil dari konsumsi masyarakat berpengaruh dalam mempercepat inflasi secara positif dan secara langsung dalam jangka panjang, dan M1 diesquilbria dimaksud tidak mempunyai efek jangka panjang apapun terhadap pertumbuhan riil dari konsumsi domestik masyarakat.

Anglingkusumo menyampaikan lebih lanjut bahwa komitmen yang tegas dan konsisten dalam menjaga kestabilan moneter secara jelas akan meningkatkan kinerja kerangka kebijakan moneter yang diterapkan. Dalam kaitan ini, untuk menyempurnakan lebih lanjut efektivitas kebijakan moneter dalam pengendalian inflasi ke depan, penulis menyarankan diterapkannya strategi yang sarat informasi dalam perumusan kebijakan moneter seperti yang diterapkan oleh Europeran Central Bank(ECB). Pilar pertama dari strategi dimaksud berisi analisis moneter atas inflasi sejalan dengan pandangan Monetarist, yaitu dengan memberikan peran yang utama pada risiko uang terhadap inflasi seperti diisyaratkan oleh kelebihan pertumbuhan uang di atas jumlah kebutuhannya. Analisis pada pilar kedua dikaitkan dengan teori-teori non-moneter atas inflasi, seperti kaitan inflasi-kesenjangan output pada New Keynessian, analisis Keynessian tradisional mengenai demand pull-cost push terhadap inflasi, hipothesis struktural, dan sebagainya. Kedua pilar analisis tersebut kemudian dikombinasikan dalam merumuskan stance kebijakan moneter dan dalam

3 Untuk studi-studi sebelumnya mengenai persiapan Bank Indonesia dalam menerapkan kerangka inflation targeting, lihat Alamsyah, dkk (2001), Sitorus (2000), dan Warjiyo (2002). Studi-studi terbaru mengenai mekanisme transmisi kebijakan moneter dapat ditemukan pada Warjiyo dan Agung (2002). 
memutuskan arah suku bunga ke depan yang diperlukan untuk mencapai tujuan utama yaitu kestabilan harga.

Artikel kedua berjudul “ The Optimal Monetary Instruments: The Case for Indonesia” merupakan upaya Affandi untuk memberikan bukti empiris mengenai keampuhan pentargetan pasokan uang vis-a-vis pentargetan suku bunga berdasarkan argumen Poole mengenai kebijakan moneter optimal. Secara teoritis, seperti yang telah dikemukakan oleh Poole, jika kejutan riil mendominasi perekonomian maka pentargetan pasokan uang akan lebih superior dalam meminimalkan kerugian pada pertumbuhan output, sementara pentargetan suku bunga akan lebih tepat apabila kejutan moneter lebih mendominasi perekonomian. Untuk kasus Indonesia, Affandi menemukan bahwa pada periode sebelum krisis pentargetan pasokan uang lebih baik dalam meminimalkan fungsi kerugian pada kebijakan moneter yang optimal, sehingga mendukung penggunaan yang luas atas besaranbesaran moneter sebagai target antara oleh bank sentral dalam dekade 1980an.

Di sisi lain, bukti empiris untuk periode setelah krisis tidak terlalu jelas untuk dapat menyimpulkan instrumen kebijakan moneter mana yang dapat meminimalkan fungsi kerugian output. Namun demikian, penulis berpendapat lebih mendukung penggunaan suku bunga sebagai instrumen kebijakan, khususnya sejak Bank Indonesia menetapkan target inflasi sebagai sasaran akhir kebijakan moneternya. Hal ini mengingat semakin melemahnya hubungan antara besaran moneter dengan tingkat inflasi sejak terjadinya perkembangan pesat di sektor keuangan, yang pada gilirannya menurunkan efektivitas besaran moneter sebagai target antara dalam kebijakan moneter. Dengan demikian, penulis mendukung upaya untuk beralih kepada kerangka kebijakan moneter yang baru berdasarkan inflation targeting.

Artikel ketiga adalah studi Sukatrilaksana mengenai “Effect of Minimum Wages on Employment in Indonesia". Upah minimum telah menjadi salah satu pertimbangan utama di Indonesia pada beberapa tahun terakhir, setelah pemerintah secara kuat menempuh kebijakan upah minimum. Tingkat upah minimum regional telah dinaikkan dengan tingkat yang relatif besar sejak tahun 1989, dan terdapat kekhawatiran bahwa kenaikan tersebut mungkin telah menurunkan pertumbuhan kesempatan kerja. Karena itu, studi ini meneliti dampak kesempatan kerja dari kenaikan upah minimum tersebut dengan menggunakan data untuk 26 propinsi dalam periode dari tahun 1988 hingga 1999. Studi memfokuskan pada beberapa kelompok pekerja di sektor formal perkotaan, yaitu laki-laki, perempuan, dewasa, muda, berpendidikan dan kurang berpendidikan, dengan menggunakan hasil dua penelitian sebelumnya mengenai pasar tenaga kerja Indonesia sebagai pembanding. 
Hasil dari analisis grafis untuk sejumlah propinsi yang mewakili pangsa terbesar dari pekerja formal perkotaan menunjukkan bahwa telah terjadi hubungan negatif antara rasio upah minimum terhadap upah rata-rata dan rasio kesempatan kerja. Lebih jauh lagi, analisis statistik menunjukkan dukungannya terhadap teori konvensional mengenai efek negatif dari upah minimum. Hasil dari seluruh alternatif spesifikasi model menunjukkan bahwa upah minimum mempunyai dampak negatif terhadap kesempatan kerja pada kelompok-kelompok yang paling sensistif terhadap perubahan parameter rejim upah minimum, yaitu kelompok pekerja perempuan, muda dan kurang berpendidikan. Sebagai salah satu implikasi dari penemuan ini, kenaikan upah minimum yang lebih tinggi dari keuntungan produktivitas dapat menurunkan daya saing ekspor Indonesia dan menciptakan suatu hambatan bagi investasi baru. Karena itu, penulis menyarankan agar pemerintah perlu menjaga upah minimum sejalan dengan produktivitas pada tingkat perusahaan, misalnya melalui negosiasi antara perusahaan dengan serikat pekerja.

Artikel terakhir merupakan studi Setiawan mengenai "Lessons from Argentine's Currency Board System (CBS) for Indonesia". Studi ini merupakan suatu upaya untuk memberikan argumen penolakan yang meyakinkan atas suatu usulan penerapan CBS yang pernah mencuat pada awal tahun 1998 untuk menangani krisis ekonomi dan keuangan Indonesia. Untuk maksud ini, studi ini mengkaji kinerja ekonomi Argentina sebelum dan sesudah implementasi CBS melalui penelaahan terhadap sejumlah indikator makroekonomi seperti pertumbuhan GDP riil, suku bunga, uang beredar dan inflas, maupun kondisi fiskal. Secara ringkas, studi menemukan bahwa setelah penerapan CBS pertumbuhan ekonomi Argentina membaik secara berarti. Suku bunga juga cenderung mengarah pada suku bunga Amerika Serikat (AS), dan tingkat inflasi mengkait pada pertumbuhan uang yang diturunkan hingga tingkat yang rendah mendekati tingkat inflasi AS.

Namun demikian, studi ini juga mengungkapkan sejumlah penemuan yang lebih penting yang memberikan pelajaran mengenai bahayanya penerapan CBS untuk Indonesia. Pertama, sustainabilitas jangka panjang dari pertumbuhan ekonomi di Argentina dengan CBS-nya sangat diragukan dengan terjadinya krisis pada tahun 2002. Kedua, konvergensi suku bunga riil dengan suku bunga AS ternyata kemudian terputus dengan tingginya risiko kemacetan kewajiban luar negeri dan munculnya ekspektasi deflasi di Argentina. Ketiga, inflasi yang rendah kemudian berubah menjadi deflasi sebagai salah satu konsekuensi dari nilai tukar nominal yang overvalued. Keempat, kurang sehatnya kebijakan fiskal dan lemahnya kondisi fiskal telah melemahkan kelanjutan CBS. Dan akhirnya, studi mengemukakan bahwa ketiadaaan fungsi lender of last resort dari bank sentral menjadi kelemahan institusional utama dari CBS. Penemuan-penemuan ini semakin melengkapi sejumlah argumen yang 
telah disampaikan oleh Speigel (1998) mengenai alasan-alasan pokok kenapa CBS tidak sesuai untuk Indonesia, yaitu bahwa: sistem ini akan terlalu mahal untuk dipertahankan, tingkat ketidakpastian mengenai nilai tukar Rupiah yang "benar" sebagai dasar penerapannya, dan akhirnya, peningkatan jumlah cadangan devisa untuk menerapkan CBS akan menimbulkan beban yang sangat besar terhadap kondisi fiskal yang sudah berat.

\section{Kepustakaan}

Alamsyah, Halim, Charles Joseph, Juda Agung, and Doddy Zulverdy (2001). “Towards Implementation of Inflation Targeting in Indonesia". Bulletin of Indonesian Economic Studies, Vol 37, No 3, pp: 309-24.

Sitorus, Tarmiden (2000), "Towards the Implementation of Inflation Targeting in Indonesia: Review of Operational Issues" in Charles Joseph and Anton Gunawan, Monetary Policy and Inflation Targeting in Emerging Economies, Jakarta: Bank Indonesia.

Walsh, Carl E. (2001), Monetary Theory and Policy, The MIT Press, Cambridge, Massachusetts, Third Printing.

Warjiyo, Perry (2002), "Towards Inflation Targeting: The Case of Indonesia" in Inflation Targeting: Theories, Empirical Models and Implementation in Pacific Basin Countries. Bank of Korea, Seoul.

Warjiyo, Perry and Juda Agung (2002), Monetary Policy Transmission of Monetary Policy in Indonesia. Bank Indonesia, Jakarta. 